\title{
MULTIPLIKASI TUNAS PUCUK TOMAT (Lycopersicum esculentum MILL) DENGAN MENGGUNAKAN BENZYL AMINO PURINE (BAP) DAN NAPHTALENE ACETIC ACID (NAA) SECARA IN VITRO
}

The Shoots Multiplication Tomato (Lycopersicum Esculentum Mill) Using Bap (Benzyl Amino Purine) And Naa (Naphtalene Acetic Acid) In Vitro

Fathurrahman, T. Rosmawati, Ahmad Syaifuddin Nst, Gunawan S.

Laboratorium Bioteknologi Fakultas Pertanian, Universitas Islam Riau, Jl. Kaharuddin Nasution No. 113 Pekanbaru Telp.0761-72126 ext. 123, Fax : 0761-674834

\begin{abstract}
Research with the title shoot multiplication shoots tomatoes (Lycopersicum esculentum mill) using the Benzyl Amino Purine (BAP) dan Naphtalene Acetic Acid (NAA) in vitro have been conducted at the Laboratory of Biotechnology Faculty of Agriculture, Islamic University of Riau, Pekanbaru. This research has been carried out for three months carried out startingfrom November 2010 to February 2011. This study aims to determine the effect of a single interaction between the administration and plant growth regulators BAP and NAA on shoot multiplication of in tomato shoots vitro. Rancangan used in this study was completely randomized design (CRD) in factorial which consist of two factors. The first factor is factor $B$ (concentration of BAP) with four standard treatments are: $B_{0}(0 \mathrm{ppm}), B_{1}(1 \mathrm{ppm}), B_{2}(2 \mathrm{ppm}), B_{3}(3 \mathrm{ppm})$.The second factor is the factor (the concentration of NAA) with four standard treatments, including: $N_{0}(0 \mathrm{ppm}), N_{1}(0.1 \mathrm{ppm}), N_{2}(0.5 \mathrm{ppm})$, and $N_{3}(1 \mathrm{ppm})$, to obtain 16 combined treatment with three replications. Parameters observed, namely: age emerged shoots, number of shoots, shoot height, the percentage of growing shoots, roots and growing percentage of the number of explants forming callus. The data was statistically analyzed the results of observations, when the $F$ calculated is greater than the F table, followed by a further test of honest real difference (HRD) 5\%. From the results of research in the interaction of BAP and NAA effect on the parameters of high-shoots by treatment tebaik $B_{1} N_{0}$ namely $6.16 \mathrm{~cm}$. BAP singly significantly affect the parameters age appears buds (days) and the percentage grows shoots with the best treatment $B_{2}(2$ ppm), shoot height with the best treatment $B_{0}(0 \mathrm{ppm})$, the number of shoots (the fruit) with the best treatment $B_{3}(3 \mathrm{ppm})$. singly whereas NAA significantly affect the parameters age appears shoots (day) and high-shoots with the best treatment $N_{0}(0$ ppm), and the percentage grows roots with the best treatment $N_{3}(1$ ppm).
\end{abstract}

Keywords : Multiflication, tomato, Benzyl Amino Purine (BAP), Naphtalene Acetic Acid (NAA), callus

\section{PENDAHULUAN}

Tanaman tomat (Lycopersicum esculentum Mill) dapat dinikmati dalam berbagai bentuk. Tomat segar dapat dijadikan sayuran, jus, atau campuran bumbu masak. Buah tomat juga banyak dimanfaatkan sebagai bahan baku industri, misalnya tomat segar dapat diolah menjadi saus, bahan kosmetik, 
bahkan sebagai bahan obat-obatan. Dalam buah tomat terdapat kandungan vitamin yang cukup lengkap sehingga buah tomat dipercaya dapat menyembuhkan berbagai penyakit.

$$
\text { Namun tanaman tomat }
$$

mempunyai berbagai penyakit yang menyerang seperti layu fusarium sehingga apabila tanaman tomat terserang penyakit tersebut mengakibatkan tanaman tomat akan mati. Salah satu cara yang dilakukan untuk mendapatkan bibit tomat yang baik dan bebas penyakit yaitu dengan cara kultur jaringan.

Kultur jaringan merupakan teknik perbanyakan tanaman dengan cara mengisolasi bagian tanaman seperti pucuk, daun, mata tunas, yang kemudian menumbuhkan bagianbagian tersebut dalam media buatan secara aseptik yang kaya akan nutrisi dan zat pengatur tumbuh yang tertutup dengan plastik yang tembus cahaya sehingga bagian tanaman dapat memperbanyak diri dan beregenerasi menjadi tanaman lengkap.

Dalam kultur jaringan, dua golongan zat pengatur tumbuh yang sangat penting adalah sitokinin dan auksin (Gunawan, 1998). Naphtalene acetic acid (NAA) adalah zat pengatur tumbuh yang tergolong auksin. Sedangkan Benzyl amino purine (BAP) tergolong zat pengatur tumbuh dalam kelompok sitokinin. Dalam pertumbuhan jaringan, sitokinin bersama-sama dengan auksin memberikan pengaruh interaksi terhadap deferensiasi jaringan (Sriyanti dan Wijayani, 1994).

Pada penelitian awal ini digunakan zat pengatur tumbuh BAP karena mempunyai efektifitas untuk perbanyakan tunas, mudah didapat dan harganya relatif murah dibandingkan kinetin. Selanjutnya zat pengatur tumbuh NAA bersifat lebih efektif dibandingkan IAA yang merupakan auksin alami. Penyediaan bibit tanaman tomat yang bebas penyakit melalui teknik kultur jaringan merupakan langkah awal dalam penanganan bibit dengan teknologi modern

Tujuan penelitian untuk mengetahui konsentrasi BAP dan $\mathrm{N}^{\wedge} \wedge$ terhadap multiplikasi tunas pucuk $\mathrm{t}^{\mathrm{A}}$ (Lycopersicum esculentum Mill) y terbaik secara in vitro.

\section{BAHAN DAN METODE}

Penelitian ini telah dilaksanakan di Laboratorium Bioteknologi Universitas Islam Riau Pekanbaru, mulai dari bulan November 2010 sampai dengan bulan Pebruari 2011. Bahan tanaman yang digunakan adalah pucuk tanaman Tomat (Lycopersicum esculentum Mill) Varietas Permata dengan panjang satu $\mathrm{cm}$. Bahan kimia yang digunakan dalam penelitian ini meliputi media Murashige and Skoog (MS), ZPT BAP dan NAA, agar-agar), gula, aquadest, detergent, bayclin, lampu spiritus, twin, alkohol 70\%, alkohol 90\%, plastik tahan panas (plastik kabur), aluminium foil, kertas label, dan karet gelang. Alat yang digunakan adalah botol kultur, bunsen, Laminar Air Flow Cabinet (LAFC), petridish, pinset besar, pinset kecil, dan pisau scalpel, timbangan analitik, plastik, hand sprayer,kompor gas, panci untuk memasak media, gunting, magnetik stirer, labu takar, breker glass, micro pipet, erlenmeyer, $\mathrm{pH}$ meter, autoclave, pipet ukur, lemari pendingin, $\mathrm{AC}$ (air conditioner), sarung tangan anti panas, alat tulis, kamera, penggaris dan rak kultur.

Penelitian ini menggunakan Rancang Acak Lengkap (RAL) faktorial yang terdiri dari dua faktor yaitu B (BAP) terdiri dari empat taraf dan $\mathrm{N}$ (NAA) empat taraf dan didapat 16 
kombinasi perlakuan dengan 3 kali ulangan sehingga diperoleh 48 botol kultur. Setiap unit percobaan satu botol yang masing-masing botol berisi tiga eksplan. Data hasil pengamatan dari masing-masing perlakuan dianalisis secara statistik, apabila $\mathrm{F}$ hitung lebih besar dari $\mathrm{F}$ tabel maka dilanjutkan dengan uji lanjut BNJ (Beda Nyata Jujur) pada taraf 5\%.

\section{HASIL DAN PEMBAHASAN}

Untuk multiplikasi eksplan ke dalam medium tumbuh dengan jenis dan konsentrasi ZPT BAP dan NAA yang berbeda-beda ada yang memberikan respon dan terdapat pula yang kurang memberikan respon. Walaupun sebagian analisa yang telah dilakukan secara uji lanjut hanya beberapa perlakukan saja yang berbeda nyata, namun secara angka-angka terdapat perbedaan yang nyata.

\section{Umur Muncul Tunas/Shoot (hari)}

Analisa sidik ragam terhadap umur muncul tunas menunjukkan bahwa secara interaksi pemberian konsentrasi BAP dan konsentrasi NAA tidak berpengaruh yang nyata. Sedangkan secara tunggal pemberian konsentrasi BAP dan NAA memberikan pengaruh yang nyata terhadap umur muncul tunas pucuk tomat. Rerata hasil umur muncul tunas pucuk tomat menurut uji lanjut BNJ pada taraf $5 \%$ dapat dilihat pada tabel dibawah ini :

Tabel 1. Rerata pengamatan umur muncul tunas pucuk tomat dengan konsentrasi perlakuan BAP dan NAA (hari).

\begin{tabular}{|c|c|c|c|c|c|}
\hline \multirow[b]{2}{*}{$\begin{array}{c}\text { Konsentrasi } \\
\text { BAP }\end{array}$} & \multicolumn{4}{|c|}{ Konsentrasi NAA } & \multirow[b]{2}{*}{ Rerata } \\
\hline & $\begin{array}{c}\mathrm{N}_{0} \\
(0 \mathrm{ppm})\end{array}$ & $\begin{array}{c}\mathrm{N}_{1} \\
(0,1 \mathrm{ppm})\end{array}$ & $\begin{array}{c}\mathrm{N}_{2} \\
(0,5 \mathrm{ppm})\end{array}$ & $\begin{array}{c}\mathrm{N}_{3} \\
(1 \mathrm{ppm})\end{array}$ & \\
\hline $\mathrm{B}_{0}(0 \mathrm{ppm})$ & 13.5 & 14,5 & 13,83 & 14,66 & $14,12 \mathrm{~b}$ \\
\hline $\mathrm{B}_{1}(1 \mathrm{ppm})$ & 10,66 & 12,83 & 13,67 & 15,5 & $13,16 \mathrm{a}$ \\
\hline $\mathrm{B}_{2}(2 \mathrm{ppm})$ & 10,66 & 13,16 & 14,33 & 15,00 & $13,28 \mathrm{a}$ \\
\hline $\mathrm{B}_{3}(3 \mathrm{ppm})$ & 13,00 & 13,66 & 15,33 & 15,16 & $14,28 \mathrm{~b}$ \\
\hline Rerata & $11,95 \mathrm{a}$ & $13,53 \mathrm{~b}$ & $14,28 \mathrm{~b}$ & $15,08 \mathrm{~b}$ & \\
\hline
\end{tabular}

Angka pada kolom dan baris yang diikuti huruf kecil yang sama tidak berbeda nyata menurut uji lanjut BNJ pada taraf $5 \%$

Berdasarkan Tabel 1 memperlihatkan interaksi perlakuan BAP dan NAA tidak berbeda nyata terhadap umur muncul tunas pucuk tomat. Secara tunggal perlakuan $\mathrm{B}_{1} \quad(1 \mathrm{ppm}) \quad$ menghasilkan yang tertinggi yaitu 13,16 hari. Respon terhadap BAP diduga telah memenuhi, dimana dengan pemberian BAP 1 ppm dapat mempercepat munculnya tunas dan semakin tinggi konsentrasi umur muncul tunas semakin lambat. Sementara itu perlakuan tanpa pemberian NAA $\left(\mathrm{N}_{0}=0 \quad \mathrm{ppm}\right)$ menghasilkan muncul tunas pucuk tomat lebih cepat yakni rata-rata 11,95 hari dan yang paling lama muncul tunasnya adalah perlakuan $\mathrm{N}_{3}$ (1 ppm) 15,08 hari. Rendahnya respon tumbuh tunas ketika pertama melakukan inisiasi eksplan ketika diberi perlakuan mengindikasikan bahwa untuk tahap inisiasi pertama eksplan tidak membutuhkan ZPT NAA. Diduga NAA eksogen ini sangat rendah dalam membantu proses pembelahan sel untuk pembentukan tunas dan hal ini terkesan tidak efektifnya pemberian NAA pada 
awal inisiasi dibandingkan dengan BAP yang relatif efektif. Lingga (1996), mengemukakan bahwa zat pengatur tumbuh merupakan senyawa organik yang dalam jumlah tertentu dapat memacu atau menghambat proses fisiologis tanaman, berpengaruh terhadap berbagai aspek pertumbuhan, differensiasi jaringan-jaringan maupun organ tanaman. Skoog dan Miller (1952), mendemonstrasikan bahwa nisbah sitokinin dan auksin yang tinggi mendorong pembentukan tunas. Namun dengan beberapa pengecualian, hubungan antara sitokinin dan auksin dalam mengontrol regenerasi tunas berlaku untuk berbagai spesies tanaman (Yusnita, 2003). Hal yang sama dinyatakan oleh George dan Sherrington (1984), bahwa inisiasi tunas dan akar ditentukan oleh konsentrasi sitokinin dan auksin yang diberikan ke dalam media dan interaksinya dengan sitokinin atau auksin endogen yang dikandung oleh eksplan.

Sedangkan hasil penelitian Nirmala (2005), pengaruh 2.4-D dan kombinasi NAA dengan kinetin terhadap pertumbuhan $\mathrm{B}_{1} \mathrm{~N}_{0}$ an perkecambahan kalus ....lat (Lycopersicon esculentum mill) varietas Kemir terbentuknya tunas pada umur 20 hari setelah tanam dengan pemberian kinetin $0,3 \mathrm{ppm}$. Hal ini diduga bahwa pada eksplan kotiledon tomat diperlukan tambahan sitokinin dalam konsentrasi yang lebih tinggi dari 0,3 ppm kinetin. Pemberian sitokinin sampai taraf tertentu berpengaruh dalam memacu waktu pembentukan tunas, hal tersebut sesuai dengan fungsi sitokinin untuk merangsang pembentukan tunas. Winarsih dkk (1998) mengemukakan bahwa sitokinin (BAP) dapat memacu pertumbuhan tunas serta Katuk (1989) cit. Simatupang (1996), menyatakan adanya sitokinin dalam kultur in vitro mempunyai peran sebagai perangsang tunas. Wetherell (1992) menyatakan bahwa sitokinin mempunyai peran yang penting untuk propagasi secara in vitro dan mendorong pertumbuhan tunas. George dan Sherrington (1984), menyatakan apabila ketersediaan sitokinin di dalam medium kultur sangat terbatas maka pembelahan sel pada jaringan yang dikulturkan akan terhambat. Apabila jaringan tersebut disubkulturkan pada medium dengan kandungan sitokinin yang memadai maka pembelahan sel akan berlangsung secara sinkron.

Tersedianya fitohormon yang terdapat dalam eksplan untuk merangsang aktifitas pembelahan sel dan pembesaran sel serta peranan unsur hara yang terdapat dalam media MS mempengaruhi munculnya tunas.

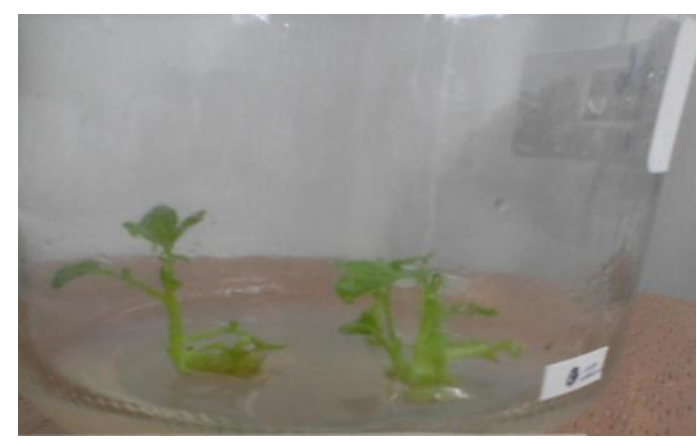

Gambar 1. Keadaan eksplan pada saat 27 hari setelah inisiasi pada perlakuan $\mathrm{B}_{1} \mathrm{~N}_{0}$ ( BAP 1 ppm, NAA 0 ppm).

Pada gambar 1 terlihat pada perlakuan $\mathrm{B}_{1} \mathrm{~N}_{0}$ eksplan sudah membentuk tunas tetapi akarnya belum muncul, dan tidak ada terbentuk kalus. Pada gambar diatas menunjukkan perlakuan yang tercepat keluarnya tunas pucuk eksplan tomat. Eksplan tumbuh dengan subur ditandai warna daun dan batang yang hijau segar dan tidak terbentuknya getah fenolik dalam media terutama disekitar eksplan. 
Jumlah Tunas/Shoot (Buah)

Hasil pengamatan terhadap jumlah tunas setelah dilakukan analisis sidik ragam menunjukkan bahwa secara interaksi konsentrasi BAP dan konsentrasi NAA tidak memberikan pengaruh yang nyata terhadap jumlah tunas pucuk tomat. Sedangkan secara tunggal pemberian konsentrasi BAP dan NAA memberikan pengaruh yang nyata terhadap jumlah tunas pucuk tomat. Rerata jumlah tunas pucuk tomat setelah diuji lanjut BNJ pada taraf 5\% dapat dilihat pada tabel 2

Tabel 2. Rerata pengamatan jumlah tunas pucuk tomat dengan konsentrasi perlakuan BAP dan NAA (Buah).

\begin{tabular}{cccccc}
\hline $\begin{array}{c}\text { Konsentrasi } \\
\text { BAP }\end{array}$ & $\begin{array}{c}\mathrm{N}_{0} \\
(0 \mathrm{ppm})\end{array}$ & $\begin{array}{c}\mathrm{N}_{1} \\
(0,1 \mathrm{ppm})\end{array}$ & $\begin{array}{c}\mathrm{N}_{2} \\
(0,5 \mathrm{ppm})\end{array}$ & $\begin{array}{c}\mathrm{N}_{3} \\
(1 \mathrm{ppm})\end{array}$ & Rerata \\
\hline $\mathrm{B}_{0}(0 \mathrm{ppm})$ & 2,00 & 2,17 & 2,17 & 2,00 & $2,08 \mathrm{~d}$ \\
$\mathrm{~B}_{1}(1 \mathrm{ppm})$ & 2,33 & 2,67 & 2,33 & 2,00 & $2,33 \mathrm{c}$ \\
$\mathrm{B}_{2}(2 \mathrm{ppm})$ & 3,17 & 3,17 & 2,33 & 2,33 & $2,75 \mathrm{~b}$ \\
$\mathrm{~B}_{3}(3 \mathrm{ppm})$ & 3,83 & 3,17 & 2,50 & 2,50 & $3,00 \mathrm{a}$ \\
Rerata & $2,83 \mathrm{a}$ & $2,79 \mathrm{a}$ & $2,33 \mathrm{~b}$ & $2,20 \mathrm{~b}$ & \\
\hline
\end{tabular}

$\mathrm{KK}=5,64 \% \quad \mathrm{BNJ} \mathrm{B} / \mathrm{N}=0,13$

Angka pada kolom dan baris yang diikuti huruf kecil yang sama tidak berbeda nyata menurut uji lanjut BNJ pada taraf $5 \%$

Berdasarkan Tabel 2 diatas dapat dilihat bahwa perlakuan BAP secara tunggal memberikan pengaruh terhadap jumlah tunas pucuk tomat. Pemberian BAP 3 ppm secara tunggal menunjukkan rerata jumlah tunas terbanyak yaitu 3,00 buah. Hal ini mengindiaksikan bahwa tanpa pemberian zat pengatur tumbuh eksogen ke dalam media, hormon endogen yang ada belum mampu untuk mendorong pembelahan sel dan pembesaran sehingga pembentukan tunas yang diharapkan belum terbentuk dengan optimal. Hal ini didukung oleh Wattimena (1992) menyatakan salah satu faktor yang menunjang terlaksananya pertumbuhan pada bagian tanaman yang diperbanyak secara invitro adalah zat pengatur tumbuh.

Hasil penelitian Elimasni dkk. (2006), dilaporkan bahwa perlakuan $\mathrm{B}_{2}$ (2 mg/l 2,4 D) dan $\mathrm{B}_{3}(1 \mathrm{mg} / \mathrm{l} \mathrm{BAP})$ memberikan jumlah tunas tertinggi pada kultur biji muda terong belanda yaitu 1,90. Sitokinin (BAP) memacu pertumbuhan tunas dan pertumbuhan tunas akan meningkat apabila terdapat auksin didalam media. Menurut Winarsih et. al., (1998) bahwa jumlah tunas meningkat seiring dengan meningkatnya konsentrasi BAP. Skoog dalam Salisbury dan Ross (1992), menyatakan bahwa fungsi utama sitokinin adalah memacu pembelahan sel. Secara umum tujuan perbanyakan secara in vitro adalah regenerasi yang diharapkan menghasilkan planlet. Proses ini diawali dengan terbentuknya mata tunas yang tumbuh dan berkembang karena adanya pengaruh media dan zat pengatur tumbuh.

Wattimena

(2002), mengemukakan bahwa pemberian auksin yang rendah dan sitokinin yang lebih tinggi cenderung mendorong pembentukan tunas adventif dan juga poliferasi tunas aksilar. Sementara itu Lakitan (1996), mengemukakan bahwa kemampuan tanaman untuk membentuk tunas sangat bervariasi, tunas batang tumbuh dari tunas aksilar atau tunas lateral pada beberapa spesies tanaman. 
Perlakuan NAA secara tunggal memberikan pengaruh terhadap jumlah tunas pucuk tomat. Tanpa pemberian NAA memberikan jumlah tunas yang lebih tinggi. Namun pemberian beberapa konsentrasi NAA ternyata dapat menghambat pertumbuhan tunas. Hal ini diduga pemberian NAA eksogen dapat menghambat mekanisme BAP baik secara endogen maupun eksogen

Pada gambar 2 perlakuan $\mathrm{B}_{0} \mathrm{~N}_{0}$ terlihat eksplan sudah tinggi dan daunnya ada yang berwarna kuning. $\mathrm{B}_{1} \mathrm{~N}_{0}$ terlihat sama dengan $\mathrm{B}_{0} \mathrm{~N}_{0}$ yang daunnya ada yang berwarna kuning. $\mathrm{B}_{2} \mathrm{~N}_{0}$ terlihat masih hijau tapi tinggi eksplannya lebih rendah dari perlakuan $\mathrm{B}_{0} \mathrm{~N}_{0} \quad$ dan $\quad \mathrm{B}_{1} \mathrm{~N}_{1} . \quad \mathrm{B}_{3} \mathrm{~N}_{0}$ terlihat eksplannya masih pendek tetapi tunasnya lebih banyak dari perlakuan yang lain

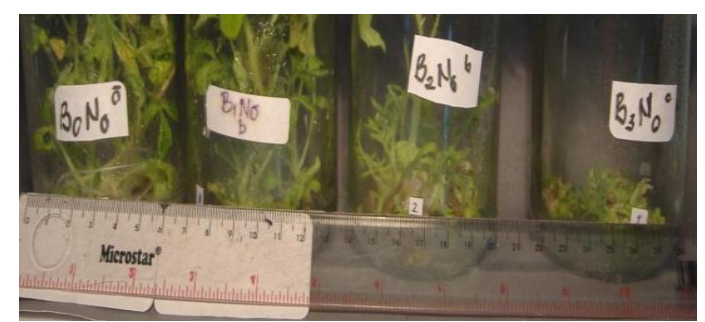

Gambar 2. Eksplan tomat yang berumur 3 bulan pada perlakuan $\mathrm{B}_{0} \mathrm{~N}_{0}$ (BAP 0 ppm, NAA 0 ppm). $\mathrm{B}_{1} \mathrm{~N}_{0}$ (BAP 1 ppm, NAA 0 ppm). $\mathrm{B}_{2} \mathrm{~N}_{0}$ (BAP 2 ppm, NAA 0 ppm). $\mathrm{B}_{3} \mathrm{~N}_{0}$ (BAP 3 ppm, NAA 0 ppm).

\section{Tinggi Tunas/Shoot $(\mathrm{cm})$}

Hasil pengamatan terhadap tinggi tunas setelah dilakukan analisis sidik ragam menunjukkan bahwa secara interaksi dan tunggal pemberian konsentrasi BAP dan konsentrasi NAA memberikan pengaruh yang nyata terhadap jumlah tunas pucuk tomat. Rerata tinggi tunas pucuk tomat menurut uji lanjut BNJ pada taraf 5\% dibawah ini.

Tabel 3. Rerata pengamatan tinggi tunas pucuk tomat dengan konsentrasi perlakuan BAP dan NAA $(\mathrm{cm})$.

\begin{tabular}{cccccc}
\hline $\begin{array}{c}\text { Perlakuan B } \\
(\mathrm{BAP})\end{array}$ & $\begin{array}{c}\mathrm{N}_{0} \\
(0 \mathrm{ppm})\end{array}$ & $\begin{array}{c}\mathrm{N}_{1} \\
(0,1 \mathrm{ppm})\end{array}$ & $\begin{array}{c}(0,5 \mathrm{ppm}) \\
\mathrm{N}_{2}\end{array}$ & $\begin{array}{c}\mathrm{N}_{3} \\
(1 \mathrm{ppm})\end{array}$ & Rerata \\
\hline $\mathrm{B}_{0}(0 \mathrm{ppm})$ & $5.83 \mathrm{a}$ & $6,00 \mathrm{a}$ & $5,33 \mathrm{a}$ & $5,33 \mathrm{a}$ & $5,62 \mathrm{a}$ \\
$\mathrm{B}_{1}(1 \mathrm{ppm})$ & $6,16 \mathrm{a}$ & $5,16 \mathrm{~b}$ & $3,33 \mathrm{c}$ & $4,83 \mathrm{~b}$ & $4,87 \mathrm{~b}$ \\
$\mathrm{~B}_{2}(2 \mathrm{ppm})$ & $4,50 \mathrm{~b}$ & $4,83 \mathrm{~b}$ & $5,16 \mathrm{a}$ & $3,33 \mathrm{c}$ & $4,41 \mathrm{c}$ \\
$\mathrm{B}_{3}(3 \mathrm{ppm})$ & $3,83 \mathrm{c}$ & $3,33 \mathrm{c}$ & $3,16 \mathrm{c}$ & $3,16 \mathrm{c}$ & $3,37 \mathrm{~d}$ \\
Rerata & $5,08 \mathrm{a}$ & $4,83 \mathrm{~b}$ & $4,24 \mathrm{c}$ & $4,16 \mathrm{c}$ & \\
\hline $\mathrm{KK}=4,07 \%$ & \multicolumn{5}{c}{$\mathrm{BNJ} \mathrm{B} / \mathrm{N}=0,16$} \\
\hline
\end{tabular}

Angka pada kolom dan baris yang diikuti huruf kecil yang sama tidak berbeda nyata menurut uji lanjut BNJ pada taraf $5 \%$

Berdasarkan Tabel 3 di atas dapat dilihat bahwa pada perlakuan tunggal setiap peningkatan konsentrasi ZPT BAP dan NAA yang diberikan ke dalam media menyebabkan lambatnya pertumbuhan tinggi eksplan tomat di bandingkan tanpa pemberian ZPT. Hal ini diduga untuk pertumbuhan tinggi ekplan, tidak memerlukan ZPT eksogen. Apabila dilakukan pemberian ZPT eksogen menyebabkan terganggunya proses pembelahan sel yang mengarah kepada tinggi eksplan. Jadi inisiasi media yang diberikan ZPT eksogen BAP dan NAA ketika eksplan sudah berumur diatas dua bulan tidak 
efektif lagi dalam membantu proses pembelahan dan pemanjangan sel, bahkan terkesan dapat menghambat.

Gunawan

(1998)

mengemukakan berhasilnya pertumbuhan tunas selain ditentukan oleh jenis dan kadar karbon pertumbuhan juga bergantung pada sumber jaringan serta kadar medium hara. Unsur hara yang diserap tersedia bagi tanaman mendorong aktifitas metabolisme dalam jaringan tanaman tersebut dan menyebabkan sel-sel tanaman akan membelah. Tingginya kemampuan jaringan untuk tumbuh, tergantung pada kemampuan auksin dan sitokinin yang ditambahkan ke dalam media untuk merubah zat pengatur tumbuh endogen dalam sel.

Berdasarkan Tabel 3 diketahui kombinasi perlakuan $\mathrm{B}_{1} \mathrm{~N}_{0}$ (BAP $1 \mathrm{ppm}$ dan NAA $0 \mathrm{ppm}$ ) menghasilkan tinggi tunas tertinggi yaitu $6,16 \mathrm{~cm}$. Berarti dengan penambahan NAA telah mampu menginduksi pembentukan tunas baru. dengan penambahan BAP saja tanpa NAA mampu menginduksi sel-sel tanaman untuk terus berkembang dan bertambah ukurannya. Hendaryono dan Wijayanti (1984) yang mengemukakan bahwa rasio antara auksin dan sitokinin akan menentukan kecepatan pembelahan sel. Abidin (1995), mengemukakan bahwa zat pengatur tumbuh merupakan senyawa organik bukan nutrisi yang aktif dalam konsentrasi rendah dapat merangsang, menghambat atau merubah pertumbuhan tanaman secara kualitatif maupun kuantitatif. Zat pengatur tumbuh BAP merupakan zat pengatur tumbuh yang termasuk kedalam golongan sitokinin dari sekian banyak pengelompokan zat pengatur tumbuh.

\section{Persentase Tumbuh Tunas/Shoot} (\%)

Hasil pengamatan terhadap persentase tumbuh tunas setelah dilakukan analisis sidik ragam menunjukkan bahwa secara interaksi pemberian konsentrasi BAP dan konsentrasi NAA tidak memberikan pengaruh yang nyata terhadap persentase tumbuh tunas pucuk tomat. Sedangkan secara tunggal pemberian konsentrasi BAP memberikan pengaruh yang nyata terhadap tinggi tunas pucuk tomat. Rerata persentase tumbuh tunas pucuk tomat menurut uji lanjut BNJ pada taraf 5\% dapat dilihat pada tabel 4 ..

Tabel 4. Rerata pada pengamatan persentase tumbuh tunas pucuk tomat dengan konsentrasi perlakuan BAP dan NAA

\begin{tabular}{cccccc}
\hline \multirow{2}{*}{$\begin{array}{c}\text { Konsentrasi } \\
\text { BAP }\end{array}$} & $\begin{array}{c}\mathrm{N}_{0} \\
(0 \mathrm{ppm})\end{array}$ & $\begin{array}{c}\mathrm{N}_{1} \\
(0,1 \mathrm{ppm})\end{array}$ & $\begin{array}{c}(0,5 \mathrm{ppm}) \\
\mathrm{N}_{2}\end{array}$ & $\begin{array}{c}\mathrm{N}_{3} \\
(1 \mathrm{ppm})\end{array}$ & Rerata \\
\hline $\mathrm{B}_{0}(0 \mathrm{ppm})$ & 44,44 & 44,44 & 55,57 & 44,44 & $47,22 \mathrm{c}$ \\
$\mathrm{B}_{1}(1 \mathrm{ppm})$ & 44,44 & 55,57 & 55,57 & 66,67 & $55,56 \mathrm{~b}$ \\
$\mathrm{~B}_{2}(2 \mathrm{ppm})$ & 66,67 & 88,89 & 77,77 & 66,67 & $75,00 \mathrm{a}$ \\
$\mathrm{B}_{3}(3 \mathrm{ppm})$ & 44,44 & 88,89 & 88,89 & 55,57 & $69,44 \mathrm{a}$ \\
Rerata & 49,99 & 69,44 & 69,45 & 58,33 & \\
\hline
\end{tabular}

$\mathrm{KK}=31,13 \% \quad \mathrm{BNJ} \mathrm{B}=6,15$

Angka pada kolom dan baris yang diikuti huruf kecil yang sama tidak berbeda nyata menurut uji lanjut BNJ pada taraf $5 \%$

Pada pemberian BAP menunjukkan pengaruh yang nyata terhadap persentase tumbuh tunas.
Perlakuan $\mathrm{B}_{2}$ menghasilkan persentase tumbuh tunas tertinggai yaitu 75,00 sehingga berbeda nyata dengan 
perlaukuan $\mathrm{B}_{1}$ dan $\mathrm{B}_{0}$. sedangkan $\mathrm{B}_{2}$ tidak berbeda nyata dengan $\mathrm{B}_{3}$.

Sitokinin adalah senyawa yang dapat meningkatkan pembelahan sel pada jaringan tanaman serta mengatur pertumbuhan dan perkembangan tanaman, sama halnya dengan kinetin (6-furfurylaminopurine) (Zulkarnain, 2009). Sitokinin berperan merangsang pertumbuhan sel dalam jaringan yang disebut eksplan dan merangsang pertumbuhan tunas daun (Wetherell, 1987).

Keberhasilan sebuah penelitian in vitro selain penambahan nutrisi dan zat pengatur tumbuh yang tepat, juga upaya mengkondisikan lingkungan kultur yang suci hama dan mencegah terjadinya kontaminasi yang dapat menurunkan tingkat keberhasilan pertumbuhan tunas. Senyawa tersebut dapat mningkatkan pembelahan sel, poliferase pucuk, dan morfogenesis pucuk ( Smith, et. al. 1992). Setiap jenis tanaman mempunyai pengaruh yang berbeda terhadap pemberian zat pengatur tumbuh, namun pada dasarnya ketersediaan hara dalam media juga mampu mendorong aktifitas metabolisme dalam jaringan tanaman namun pertumbuhan tunas akan berlangsung lambat jika tanpa pemberian zat pengatur tumbuh.

Pada pemberian BAP $1 \mathrm{ppm}$ belum mampu meningkatkan aktifitas pembelahan sel untuk menumbuhkan tunas. Sedangkan pemberian BAP 3 ppm belum mampu meningkatkan pertumbuhan karena konsentrasi kemungkinan terlalu tinggi sehingga BAP tersebut menghambat proses pembentukan tunas.

\section{Persentase Tumbuh Akar (Root)}

Secara interaksi pemberian konsentrasi BAP dan konsentrasi NAA tidak memberikan pengaruh yang nyata terhadap persentase tumbuh akar pucuk tomat. Sedangkan secara tunggal pemberian konsentrasi NAA memberikan pengaruh yang nyata terhadap persentase tumbuh akar pucuk tomat. Rerata persentase tumbuh akar pucuk tomat menurut uji lanjut BNJ pada taraf 5\% dapat dilihat pada tabel dibawah ini.

Tabel 5. Rerata pada pengamatan persentase tumbuh akar pucuk tomat dengan konsentrasi perlakuan BAP dan NAA

\begin{tabular}{cccccc}
\hline $\begin{array}{c}\text { Perlakuan B } \\
(\text { BAP })\end{array}$ & $\begin{array}{c}\mathrm{N}_{0} \\
(0 \mathrm{ppm})\end{array}$ & $\begin{array}{c}\mathrm{N}_{1} \\
(0,1 \mathrm{ppm})\end{array}$ & $\begin{array}{c}\mathrm{N}_{2} \\
(0,5 \mathrm{ppm})\end{array}$ & $\begin{array}{c}\mathrm{N}_{3} \\
(1 \mathrm{ppm})\end{array}$ & Rerata \\
\hline $\mathrm{B}_{0}(0 \mathrm{ppm})$ & 33,33 & 55,57 & 66,67 & 77,77 & 58,33 \\
$\mathrm{~B}_{1}(1 \mathrm{ppm})$ & 33,33 & 44,44 & 77,77 & 77,77 & 58,33 \\
$\mathrm{~B}_{2}(2 \mathrm{ppm})$ & 44,44 & 55,57 & 66,67 & 66,67 & 58,33 \\
$\mathrm{~B}_{3}(3 \mathrm{ppm})$ & 44,44 & 55,57 & 77,77 & 77,77 & 63,88 \\
Rerata & $38,88 \mathrm{c}$ & $52,78 \mathrm{~b}$ & $72,22 \mathrm{a}$ & $74,99 \mathrm{a}$ & \\
\hline
\end{tabular}

$\mathrm{KK}=41,08 \quad \mathrm{BNJ} \mathrm{N}=7,84$

Angka pada kolom dan baris yang diikuti huruf kecil yang sama tidak berbeda nyata menurut uji lanjut BNJ pada taraf $5 \%$

Dari Tabel 5 diatas dapat dilihat bahwa secara tunggal pemberian perlakuan NAA berpengaruh nyata terhadap persentase tumbuh akar eksplan pucuk tomat. Perlakuan
$\mathrm{N}_{3}$ (1 ppm) berbeda nyata dengan perlakuan $\mathrm{N}_{1}(0,1 \mathrm{ppm})$ dan $\mathrm{N}_{0}(0 \mathrm{ppm})$. Hal ini diduga bahwa pemberian NAA dengan konsentrasi 1 ppm masih mampu meningkatkan pertumbuhan 
akar dan tidak mengganggu aktifitas fisiologis dalam sistem jaringan eksplan. Pemberian zat pengatur tumbuh yang sesuai sangat diperlukan, sebab jika diberikan dalam jumlah yang sedikit akan mengganggu pertumbuhan eksplan dan jika diberikan dalam jumlah yang banyak juga akan berpengaruh pada pertumbuhan tanaman. Keberadaan sitokinin juga menghambat kerja auksin dalam hal pemanjangan sel pada hipokotil. Son et. al., (2004) juga mengemukakan bahwa transport auksin dihambat oleh penambahan sitokinin dalam hal pemanjangan akar pada daerah meristem apikal akar. Dengan konsentrasi 0,5 ppm NAA juga masih dapat meningkatkan persentase pembentukan akar. Dengan terbentuknya akar maka akan semakin banyak unsur hara yang diabsorbsi dari media tanam,sehingga perkembangan eksplan menjadi lebih baik.

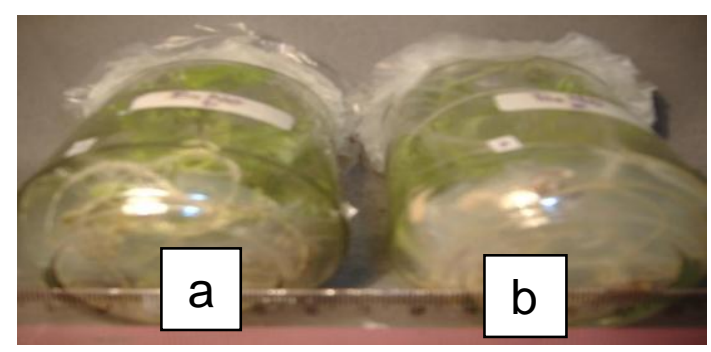

Gambar 3. Perakaran tomat yang tumbuh pada akhir penelitian pada $\mathrm{a}=$ perlakuan $\mathrm{B}_{1} \mathrm{~N}_{2}$ dan $\mathrm{b}=$ perlakuan $\mathrm{B}_{2} \mathrm{~N}_{2}$

Dari gambar 3 terlihat bahwa pada gambar $\mathrm{B}_{1} \mathrm{~N}_{2}$ (BAP 1 ppm, NAA $0,5 \mathrm{ppm}$ ) banyak akar yang terbentuk dengan warna keputih-putihan.
Perlakuan $\mathrm{B}_{2} \mathrm{~N}_{2}$ (BAP 2 ppm, NAA 0,5 ppm) terlihat akar lebih sedikit dibandingkan dengan perlakuan $\mathrm{B}_{1} \mathrm{~N}_{2}$. Hal ini sejalan dengan azas keseimbangan auksin dan sitokinin yang dikemukakan oleh George and Sherington (1993) bahwa pembentukan akar memerlukan auksin tanpa sitokinin atau sitokinin dalam konsentrasi rendah. Secara umum, rasio sitokinin yang tinggi daripada auksin akan memicu terbentuknya tunas dan pada medium dengan konsentrasi sitokinin yang rendah tidak mampu membuat kalus terdiferensiasi menjadi tunas. Eksplan akan tumbuh dengan baik apabila tersedia cukup hara bagi tanaman. George and Sherington (1993) menyatakan bahwa auksin berpengaruh luas terhadap pertumbuhan, merangsang dan mempercepat pertumbuhan akar, serta meningkatkan kualitas dan kuantitas akar. Pada media yang ditambahkan NAA menunjukkan bahwa auksin dapat mengaktifkan enzimenzim yang berperan dalam pembuatan komponen sel sehingga begitu mulai terjadinya pembelahan sel maka NAA akan merangsang pembentukan sel sel dengan cepat (Wattimena, 1991).

\section{Jumlah Eksplan Yang Membentuk Kalus}

Hasil pengamatan terhadap jumlah eksplan yang membentuk kalus tidak dianalisis secara statistik. Rerata jumlah eksplan yang membentuk kalus dengan konsentrasi BAP dan NAA disajikan pada tabel berikut : 
Tabel 6. Rerata jumlah eksplan yang membentuk kalus dengan konsentrasi BAP dan NAA.

\begin{tabular}{ccc}
\hline Perlakuan & $\begin{array}{c}\text { Jumlah eksplan yang } \\
\text { dikulturkan }\end{array}$ & $\begin{array}{c}\text { Jumlah eksplan yang } \\
\text { membentuk kalus }\end{array}$ \\
\hline B0N0 & 9 & - \\
B0N1 & 9 & - \\
B0N2 & 9 & - \\
B0N3 & 9 & 9 \\
B1N0 & 9 & - \\
B1N1 & 9 & - \\
B1N2 & 9 & 8 \\
B1N3 & 9 & 9 \\
B2N0 & 9 & - \\
B2N1 & 9 & 9 \\
B2N2 & 9 & 7 \\
B2N3 & 9 & 6 \\
B3N0 & 9 & - \\
B3N1 & 9 & 8 \\
B3N2 & 9 & 8 \\
B3N3 & 9 & 9 \\
\hline Jumlah & 144 & 73 \\
\hline
\end{tabular}

Dari Tabel diatas dapat dilhat bahwa $\mathrm{B}_{0} \mathrm{~N}_{0}, \mathrm{~B}_{0} \mathrm{~N}_{1}, \mathrm{~B}_{0} \mathrm{~N}_{2}, \mathrm{~B}_{1} \mathrm{~N}_{0}, \mathrm{~B}_{1} \mathrm{~N}_{1}$, $\mathrm{B}_{2} \mathrm{~N}_{0}$, dan $\mathrm{B}_{3} \mathrm{~N}_{0}$ tidak ada terbentuk kalus, ini diduga karena pemberian BAP dan NAA konsentrasinya selalu berbeda dan ada yang tanpa pemberian ZPT. Sedangkan perlakuan lain terbentuk kalus pada eksplan tomat, ini diduga karena belum adanya interaksi yang cocok antara BAP dan NAA dan adanaya keseimbangan antara konsentrasi yang diberikan sehingga eksplan mengarah ke pembentukan kalus. Pada perlakuan $\mathrm{B}_{3} \mathrm{~N}_{3}$ (BAP 1 ppm, NAA 1 ppm) memberikan rasio yang seimbang diantara kelompok zat pengatur tumbuh tersebut sehingga terbentuk kalus.

Warna kalus yang terbentuk terdiri dari warna kuning muda (gambar 4.a) dan hijau kekuningan (gambar 4.b). Kalus yang terbentuk mengalami perubahan warna dari kuning menjadi hijau, tetapi ada juga yang tetap kuning atau tetap hijau. Perubahan warna kalus umumnya terjadi menjelang terbentuknya tunas. Pada gambar 4.a terlihat bahwa perlakuan $\mathrm{B}_{2} \mathrm{~N}_{1}$ a terjadi pembentukan kalus yang diiringi terbentuknya satu tunas yang berasal dari embrio somatik di kalus. Pada perlakuan $\mathrm{B}_{3} \mathrm{~N}_{3}$ b terlihat pembentukan eksplan menjadi kalus yang tidak disertai oleh terbentuknya tunas.

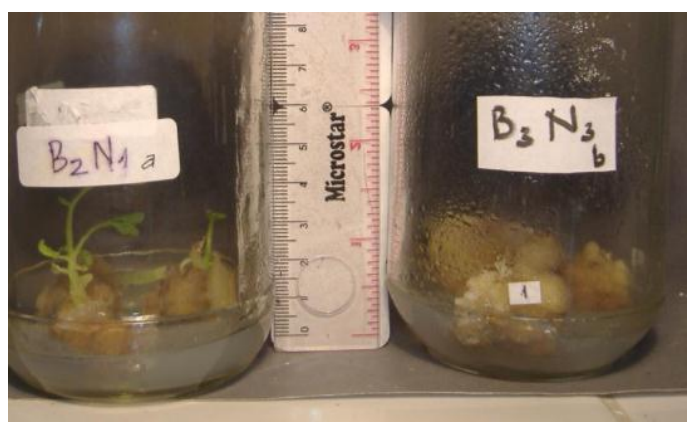

Gambar 4. Kalus yang terbentuk pada eksplan tomat. a. $\mathrm{B}_{2} \mathrm{~N}_{1}$ (BAP 2 ppm, NAA 0,1 ppm) dan b. $\mathrm{B}_{3} \mathrm{~N}_{3}$ (BAP $3 \mathrm{ppm}$, NAA 1 ppm).

Kalus adalah suatu kumpulan sel amorphous yang terjadi dari sel-sel 
jaringan yang berproliferasi secara terus menerus dan tidak terorganisasi sehingga memberikan penampilan sebagai massa sel yang bentuknya tidak teratur. Penelitian pembentukan kalus pada jaringan terluka pertama kali dilakukan oleh Sinnott pada tahun 1960. Pembentukan kalus pada jaringan luka dipacu oleh zat pengatur tumbuh auksin dan sitokinin endogen (Dodds \& Roberts, 1983).

Sistem induksi yang tepat, kalus dapat berkembang menjadi tanaman yang utuh (plantlet). Kalus terbentuk melalui tiga tahapan, yaitu induksi, pembelahan sel, dan diferensiasi. Pembentukan kalus ditentukan sumber eksplan, komposisi nutrisi pada medium dan faktor lingkungan.eksplan yang berasal dari jaringan meristem berkembang lebih cepat dibanding jaringan dari sel-sel berdinding tipis dan mengandung lignin.

Dari hasil penelitian yang dilakukan semua interaksi dari perlakuan BAP dan NAA menunjukkan non signifikan kecuali tinggi tunas, ini diduga karena konsentrasi yang diberikan belum seimbang sehingga belum mampu memberikan respon terhadap aktifitas biologis dalam tubuh eksplan.

\section{KESIMPULAN}

Dari hasil penelitian yang telah dilakukan dapat disimpulkan bahwa secara interaksi pemberian konsentrasi BAP dan NAA pada multiplikasi tunas pucuk tomat (Lycopersicum esculentum Mill) memberikan pengaruh terhadap parameter tinggi tunas dengan perlakuan tebaik $\mathrm{B}_{1} \mathrm{~N}_{0}$ yaitu $6,16 \mathrm{~cm}$. Pemberian konsentrasi BAP berpengaruh pada parameter umur muncul tunas dan persentase tumbuh tunas dengan perlakuan terbaik $\mathrm{B}_{2} \quad$ (2 ppm), tinggi tunas $B_{0}(0 \mathrm{ppm})$ jumlah tunas dengan perlakuan $\mathrm{B}_{3}(3 \mathrm{ppm})$. Sedangkan pemberian konsentrasi NAA memberikan pengaruh pada parameter umur muncul tunas, tinggi $\mathrm{dm}$ persentase tumbuh akar perlakuan terbaik $\mathrm{N}_{3}(1 \mathrm{ppm})$.

\section{DAFTAR PUSTAKA}

Abidin. 1995. Zat Pengatur Tumbuh. Angkasa. Bandung.

Dodds,Y. and L.W. Robert. 1982. Experiment in Plant Tissue Culture. Cambridge University Press. London.

Gunawan. 1998. Teknik Kultur Jaringan. Laboratorium Kultur Jaringan Tanaman. Pusat Antar Universitas Bioteknologi. IPB. Bogor.

George, E.F and Sherrington. 1984. Plant Propagation by Tissue Culture. P.D. Exegetis Limities. England. . 1993. Plant Propagation by Tissue Culture. Exegetic Limited. London.

Hendaryono, D.P.S. dan A. Wiinnni. 1994. Teknik Kultur J Pengenalan dan $p, \alpha$ perbanyakan secara VegetatifModern. Penerbit Kanisius. Yogyakarta.

Katuk, J.R.P. 1989. Teknik kultur jaringan dalam mikro propagasi tanaman. Departemen Pendidikan dan Kebudayaan Derektorat Jendral Pendidikan Tinggi Proyek Pengembangan Lembaga Pendidikan. Jakarta.

Lakitan, B. 1996. Dasar-dasar fisiologi tumbuhan. PT.Raja Grafindo Persada. Jakarta.

Nirmala, R. 2005. Pengaruh 2,4 D dan kombinasi NAA dengan kinetin terhadap pertumbuhan dan 
perkecambahan kalus tomat (Lycopersicum esculentum Mill) varietas kemir. Jurnal Agro BiogenVolume 1 Nomor 1 April 2005, hal 54-62

Salisbury, F.B. dan Ross. 1995. Fisiologi Tumbuhan Jilid 3. Terjemahan Oleh Lukman dan Sumaryono. ITB. Bandung.

Simatupang, S. 1996. Pengaruh penambahan sitokinin dan asam naftalen asetat pada media murashige dan skoog terhadap perkembangan eksplan asparagus. J. Hort. 6(2) : 105 108.

Skoog and Miller. 1953. Chemical control of bud formation in tobacco stem segments. Am. J. Bot. 40, 768-773

Smith dan Wood. 1992. Mollecular and Cell Biochemistry. Cell Biology. Chapman \& Hall. London

Son, Ora, Hee-Yeon Choa, Kim MiRan. 2004. Induction of a Homeodomain-Leucine Zipper Gene By Auxin Is Inhibited By Cytokinin In Arabidopsis Roots. Biochemica land Biophysical Research Communications 326 (2005) 203-209.Korea.

Sriyanti, D.P. dan A.Wijayani. 1994.

Teknik Kultur Jaringan.

Yayasan Kansius. Yogyakarta. $69,82-83$.

Hal. 18, 54, 57, 63, 67,

Wattimena, G.A., Gunawan, L. W., Mattjik, N.A. Sjamsudin, E., Wiendi, N.M.A. dan Ernawati, A. 1991. Bioteknologi Tanaman. Pusat Antar Universitas Institut Pertanian Bogor.

Wattimena, G. A. 1992. Diktat Zat Pengatur Tumbuh Tanaman. Laboratorium Kultur Jaringan Tanaman PAU Bioteknologi IPBDirektorat Jenderal Pendidikan Tinggi Departemen
Pendidikan dan Kebudayaan. Bogor . 1998. Zat Pengatur Tumbuh Tanaman. PAU Bioteknologi. IPB, Bogor.

Winarsih, S., Priyono, dan Zaenudin. 1998. Pengaruh zat pengatur tumbuh terhadap perbanyakan kerk lili secara in vitro. J. Hort. $8(3)$ : $1145-1152$.

Wetherell, D. F. 1982. Pengantar Provagasi Tanaman Secara InVitro. IKIP Semarang. Press Semarang.

Wetter, L. R. dan F. Constabel. 1991. Metode Kultur Jaringan Tanaman. Edisi Kedua. ITB Press. Bandung.

Yusnita. 2003. Kultur jaringan: Cara Memperbanyak Tanaman Secara Efisien. Penerbit Agromedia Pustaka. Jakarta

Zulkarnain. 2009. Kultur Jaringan Tanaman. Solusi Perbanyakan Tanaman Budi Daya. Bumi Aksara. Jakarta. 